PAWEe NowaK

Uniwersytet Pedagogiczny, Kraków, Polska

\title{
Polska w rankingach gospodarek opartych na wiedzy
}

\section{Poland in the Rankings of Knowledge Economies}

Streszczenie: Celem niniejszego artykułu jest analiza pozycji Polski w rankingach gospodarek opartych na wiedzy na tle krajów członkowskich Unii Europejskiej. Ocena oparta jest na metodologii KAM Banku Światowego, która posługuje się dwoma zagregowanymi indeksami KEI i KI. Kompleksowy wskaźnik KEI oparty jest na czterech subwskaźnikach: Reżim instytucjonalno-prawny, System innowacji, Edukacja i zasoby ludzkie, Technologie komunikacyjne i informacyjne. W artykule wykorzystano dane z 2012 roku. Pozycja Polski w rankingu pogorszyła się o 3 pozycje (38. miejsce) w stosunku do 2000 r. W drugiej części artykułu podjęto próbę identyfikacji głównych kierunków działań, do których zobowiązała się Polska w ramach realizacji strategii Europa 2020 powinny przyczynić się one do poprawy sytuacji i rozwojowi gospodarki opartej na wiedzy.

\begin{abstract}
The main aim of this article is to present the position of the Polish economy in comparison to the Member States of the European Union. The evaluation is based on the World Bank's Knowledge Assessment Methodology (KAM) that produces the Knowledge Economy Index (KEI) - an aggregate index representing a country's or region's overall preparedness to compete in the Knowledge Economy (KE). The KEI is based on a simple average of four sub-indexes, which represent the four pillars of the knowledge economy: 1) Economic Incentive and Institutional Regime, 2) Innovation and Technological Adoption, 3) Education and Training, 4) Information and Communications Technologies Infrastructure. The study utilizes the data from 2012. Poland dropped down 3 position to the $38^{\text {th }}$ place since 2000 , which is a reflection of the declines in the normalized scores for two indicators. The second part of paper deals with describing steps undertaken by Poland within the Europe 2020 strategy, whose aim is to improve its position and lead to the development of a knowledge-based economy.
\end{abstract}

Słowa kluczowe: gospodarka oparta na wiedzy, indeks KEI i KI, metodologia KAM, strategia Europa 2020

Key words: KAM methodology, KEI and KI index, knowledge economy, strategy Europe 2020 


\section{WSTĘP}

Nauka i wiedza napędzają zmiany we współczesnym świecie. Widoczne jest rosnące zapotrzebowanie gospodarek na kapitał ludzki, którego poziom zależy m.in. od ilości i jakości zasobu wiedzy. Problem ten nabiera coraz większego znaczenia również w Polsce wraz z rosnącym stopniem powiązań naszej gospodarki z gospodarką światową i przechodzeniem na wyższy poziom rozwoju cywilizacyjnego. Powszechnie rozumie się, że obecnie rozwój gospodarczy, dobrobyt społeczeństw determinowane są coraz bardziej przez potencjał wiedzy (Hryniewicz, 2010).

Jeszcze dziesięć lat temu mówienie o gospodarce opartej na wiedzy w Polsce spotykało się z dużym niezrozumieniem. Wydawało się, że jest to idea zarezerwowana wyłącznie dla środowiska naukowego, koncepcja zbyt przyszłościowa i na wyrost, być może ważna dla krajów wysoko rozwiniętych, ale nieadekwatna do miejsca i wyzwań, przed którymi stoi nasza gospodarka. Sytuacja uległa zmianie wraz z wejściem Polski w 2004 roku do Unii Europejskiej, przyjęciem przez Unię strategii lizbońskiej i nową inicjatywą Europa 2020. Nałożyło na nasz kraj obowiązek dostosowania polityki gospodarczej do celów unijnych. Powstawanie gospodarek opartych na wiedzy jest kolejnym etapem przemian cywilizacyjnych, co wymaga uwzględnienia w średnio- i długoterminowych strategiach rozwoju gospodarczego kraju (Rachwał, 2011).

Celem niniejszego artykułu jest analiza pozycji Polski w rankingach gospodarek opartych na wiedzy na tle nowych i starych krajów członkowskich Unii Europejskiej. W pracy wykorzystano informacje pochodzące z tablic Banku Światowego, zawierające dane na temat wskaźników i subwskaźników KEI i KI poszczególnych krajów w 2012 r. W drugiej części artykułu podjęto próbę identyfikacji głównych kierunków działań, do których zobowiązała się Polska w ramach realizacji strategii Europa 2020, służących rozwojowi gospodarki opartej na wiedzy.

\section{WIEDZA I GOSPODARKA OPARTA NA WIEDZY}

Zrozumienie istoty gospodarki opartej na wiedzy (GOW) wymaga zdefiniowania terminu „wiedza”, który jest ujmowany w literaturze naukowej na wiele sposobów. W opracowaniach naukowych został przyjęty model, zgodnie z którym rozróżnia się cztery fazy przetwarzania danych (Skyrme, 1999). Podstawą do tworzenia wiedzy są dane, natomiast zbiór informacji, który jest ustrukturyzowany i interpretowany, staje się wiedzą. Z kolei umiejętności używania, modyfikowania i tworzenia wiedzy to mądrość (model w ujęciu sekwencyjnym: dane $\rightarrow$ informacje $\rightarrow$ wiedza $\rightarrow$ mądrość).

Innym zagadnieniem jest relacja, jaka powstaje między wiedzą i umiejętnościami. W Polsce kładzie się obecnie nacisk na rozróżnienie tych dwóch pojęć (Witulska, 2003). W literaturze przedmiotu dotyczącej GOW przyjmuje się, że umiejętności wynikają m.in. z tzw. wiedzy cichej, ukrytej, gdyż wiedza nie jest utożsamiana jedynie ze znajomością faktów. 
Zgodnie z powszechnie przyjmowanym współcześnie na świecie podziałem dzieli się ją na dwie szerokie kategorie (Howitt, 1996):

- wiedza skodyfikowana (ang. codified knowledge) - czyli zorganizowana, usystematyzowana, zapisana, która może być przechowywana i przenoszona w różny sposób, np. w książkach, raportach, patentach, w Internecie;

- wiedza cicha (ang. tacit knowledge) - która ze swej natury jest nierozłącznie związana z ludźmi i jest rezultatem ich talentu, zdolności oraz doświadczeń; stanowi dobro specjalnego rodzaju - przez to trudno ją zmierzyć.

Względnie łatwa do zmierzenia jest wiedza pierwszego rodzaju. Mamy dziś tylko pośrednie i częściowe wskaźniki stanu wiedzy. Nieznana część wiedzy jest ukryta, nieskodyfikowana i przechowywana tylko w umysłach ludzi. Powoduje to, że skodyfikowanie gospodarki opartej na wiedzy jest bardzo trudne, właśnie m.in. ze względu na brak możliwości zmierzenia wiedzy cichej.

B. Lundvall i B. Johnson (1994) wprowadzili następujący podział wiedzy:

- wiedzieć co (ang. know-what) - ten typ wiedzy odnosi się do znajomości faktów i jest raczej identyfikowany $\mathrm{z}$ informacją;

- wiedzieć dlaczego (ang. know-why) - odnosi się do zrozumienia reguł funkcjonujących w naturze, społeczeństwie;

- wiedzieć jak (ang. know-how) - wiedza odnosząca się do umiejętności zrobienia czegoś; posiadają ją eksperci i gromadzona jest w postaci doświadczenia, a także doświadczenia wypracowanego przez firmy; dostęp publiczny do tego typu wiedzy jest bardzo ograniczony, a jej transfer - trudny;

- wiedzieć kto (ang. know-who) - są to kombinacje informacji i relacji społecznych na temat tego, kto co wie; pozwalają one na wykorzystanie wiedzy ekspertów.

Wiedza w dwóch pierwszych znaczeniach jest skodyfikowana, natomiast w pozostałych bardziej ukryta, trudniejsza do usystematyzowania i zmierzenia oraz do rozpowszechnienia w sposób formalny.

R. Solow (1957) stwierdził, że praca i kapitał przyczyniły się do wzrostu gospodarczego Stanów Zjednoczonych w latach 1909-1949 jedynie w 12,5\% . Podobnie znacznie później, tj. w 1998 r., Bank Światowy podał, że akumulacja pracy i kapitału wyjaśnia jedynie 25-30\% zróżnicowania stóp wzrostu PKB pomiędzy krajami w długim okresie (World..., 1998/1999). Kapitał i praca przestały być głównymi czynnikami wzrostu gospodarczego. Wskazano na rolę przedsiębiorczości i innowacyjności w dążeniu do wzrostu gospodarczego.

Przełom w dziedzinie badań nad gospodarką opartą na wiedzy przyniosły dopiero badania OECD i słynny raport The Knowledge-based Economy z 1996 r., w którym m.in. zdefiniowano pojęcie gospodarki opartej na wiedzy jako: „bezpośrednio bazującej na produkcji, dystrybucji i użyciu wiedzy oraz informacji”. Definicja ta jest obecnie uznawana za klasyczną. Według bardziej współczesnej definicji, pochodzącej z raportu OECD i Banku Światowego z 2001 r. gospodarka oparta na wiedzy to taka, ,gdzie wiedza jest tworzona, zdobywana, transmitowana i użyta efektywnie przez przedsiębiorstwa, organizacje, jednostki i wspólnoty". Nie jest wąsko skupiona na przemysłach zaawansowanych technologicznie lub na technologiach teleinformatycznych, ale raczej prezentuje ramy dla analizowania 
zakresu opcji politycznych w edukacji, infrastrukturze informacyjnej i systemach innowacji, które mogą pomóc rozwijać gospodarkę wiedzy (Republic..., 2012).

Omawiając gospodarkę opartą na wiedzy, należy określić czynniki, które doprowadziły do jej powstania. Najczęściej autorzy powołują się na heurystyczną koncepcję fal innowacji J. Schumpetera, które odnosiły się do przełomowych wynalazków i ich wdrożeń (Ciborowski, Grabowiecki, 2004). Zgodnie z nią, pierwsza fala rozpoczęła się ok. 1785 r. i trwała 60 lat, druga trwała 55 lat, trzecia - 50 lat, czwarta - 40 lat, a piąta - obecna, oparta na sieciach cyfrowych (digital networks), oprogramowaniu i nowych mediach ma trwać 30 lat - do $2020 \mathrm{r}$.

Zgodnie z klasyczną definicją OECD - gospodarki oparte na wiedzy to takie, które bezpośrednio bazują na produkcji, dystrybucji i użyciu wiedzy oraz informacji (The Knowledge..., 1996). W 1999 r. OECD określiło GOW jako zbiór przemysłów zaawansowanych technologii, takich jak: informatyka i telekomunikacja oraz sektorów wykwalifikowanej siły roboczej, takich jak: finanse i edukacja. Bank Światowy wyróżnia natomiast cztery tzw. filary gospodarki opartej na wiedzy, które w najlepszy sposób opisują rozwój GOW. Są to: otoczenie instytucjonalno-prawne, systemy innowacji, edukacja i zasoby ludzkie oraz technologie komunikacyjne i informacyjne. Współcześnie postuluje się konieczność rozwoju kształcenia ustawicznego, w celu niedopuszczenia do powstania czy pogłębienia się „luk wiedzy" (knowledge divie), a także poprawę jakości edukacji. Jednym z wielu sposobów dążenia do osiągnięcia tego celu jest wykorzystanie narzędzi e-learningowych.

\section{PoMIAR GOSPODAREK OPARTYCH NA WIEDZY - METODOLOGIA KAM}

Mierzenie gospodarki opartej na wiedzy, mimo coraz większej liczby opracowań na ten temat, wciąż pozostaje otwartą kwestią. Wiedza znalazła trwałe miejsce w modelach wzrostu gospodarczego, co wpłynęło korzystnie na rozwój badań w tym zakresie. Jednym z podstawowych problemów, z którymi borykają się ekonomiści, jest kwestia pomiaru - nie dotyczy ona tylko braku danych, ale deficytu teorii. Wycinkowe dane statystyczne nie dają wystarczającej i jasnej odpowiedzi na pytanie o rozmiary gospodarki opartej na wiedzy. Dlatego stosowane są indeksy kompleksowe składające się z kilku lub nawet kilkuset subwskaźników.

Niektórzy ekonomiści twierdzą nawet, że tworzy się nowy, czwarty sektor gospodarki (Machlup, 1962). Proponują więc, aby gospodarkę opartą na wiedzy mierzyć np. udziałem w PKB podobnie jak pozostałe sektory gospodarki.

Badania w zakresie rozwoju gospodarki opartej na wiedzy są dosyć skomplikowane pod względem metodologicznym. Jedną z popularniejszych metodologii badania gospodarek opartych na wiedzy jest KAM (ang. Knowledge Assessment Methodology), opracowana przez Bank Światowy w 1998 roku (Chen, Dahlaman, 2005). Metodologia ta stosowana jest do pomiaru wiedzy z wykorzystaniem licznych subwskaźników, tworzących dwa kompleksowe indeksy wiedzy: wskaźnik gospodarki opartej na wiedzy - KEI (ang. knowledge economy index) oraz wskaźnik wiedzy - KI (knowledge index). 
Bank Światowy stale udoskonala metodologię KAM od momentu, gdy została ona opracowana w ramach K4D (ang. Knowledge for Development) przez Instytut Banku Światowego oraz doczekała się aplikacji w wersji basic scorecard dostępnej na stronie internetowej.

Wskaźnik KEI służy do dokonywania porównań ekonomicznych na poziomie międzynarodowym i czasowym. Uwzględnia on również zdolność sprzyjania środowiska gospodarczego efektywnemu wykorzystywaniu wiedzy na potrzeby rozwoju ekonomicznego. Do głównych cech metodologii KAM należy przyporządkowanie poszczególnych wskaźników cząstkowych do określonych filarów modelu gospodarki opartej na wiedzy. Następnie określenie zakresu pojęciowego, znormalizowanie subwskaźników przez przypisanie określonych wartości (w przedziale od 0 do 10 - im wartości wyższe, tym większy stopień zaawansowania gospodarki opartej na wiedzy), obliczanie indeksów cząstkowych, ponowne ich ważenie i wreszcie obliczanie końcowego wskaźnika (Piech, 2006).

Wskaźnik KEI jest zbudowany na czterech filarach, z których każdy opiera się na trzech subwskaźnikach (Dahlaman, 1999):

1. „Reżim prawno-instytucjonalny”:

Pierwszy filar składa się z subwskaźników: Bariery celne i pozacelne; Jakość regulacji; Reguły prawa.

2. „Edukacja i zasoby ludzkie”:

Drugi filar składa się z subwskaźników: Stopa alfabetyzacji dorosłych; Liczba osób z wykształceniem średnim do ogółu populacji w wieku odpowiadającym uczniom szkół średnich; Udział osób odbierających edukację na poziomie wyższym do ogółu populacji w wieku odpowiadającym studentom dla szkolnictwa wyższego.

3. „System innowacji”:

Trzeci filar składa się z subwskaźników: Naukowcy w sektorze Badań i Rozwoju; Zgłoszenia patentowe przyznane przez Biuro Patentowe USA na milion mieszkańców; Liczba artykułów naukowych w czasopismach naukowych i technicznych na milion obywateli.

4. „Technologie komunikacyjne i informacyjne”:

Czwarty filar składa się z następujących subwskaźników: Telefony na 1000 osób, Komputery na 1000 osób, Użytkownicy Internetu na 10000 osób.

Wskaźnik wiedzy KI jest miarą określającą tworzenie, wykorzystywanie oraz dyfuzje wiedzy, czyli potencjał wiedzy w danej gospodarce. Metodologicznie KI stanowi prostą średnią znormalizowanych wyników kraju czy regionu według kluczowych parametrów trzech filarów gospodarki wiedzy - edukacji i zasobów ludzkich, innowacji i technologii komunikacyjnych i informacyjnych.

Bank Światowy, wykorzystując metodologię KAM, podaje corocznie wyniki krajów pod względem zaawansowania w budowę gospodarki opartej na wiedzy. Ranking dostępny jest jako część składowa aplikacji basic scorecard, umożliwiającej śledzenie na bieżąco zmian w ramach głównych indeksów KEI i KI, jak również poszczególnych czterech filarów gospodarki wiedzy oraz dającej możliwości dokonywania porównań, w tym również tempa zmian w stosunku do 1995 i 2000 roku. 
PoZYCJA PolsKi ORAZ INNYCH KRAJÓW CZlONKOWSKICH UNII EUROPEJSKIEJ W RANKINGACH WSKAŹNIKÓW I SUBWSKAŹNIKÓW KEI I KI

Liderami rankingu według najbardziej kompleksowego wskaźnika KEI są kraje skandynawskie: Szwecja, Finlandia, Dania oraz Holandia i Niemcy. Na końcu zestawienia znajdują się Łotwa, Polska, Rumunia i Bułgaria. Rumunia i Bułgaria, w przeciwieństwie do Polski, odnotowały jednak poprawę pozycji i w porównaniu z 2000 rokiem przesunęły się w górę odpowiednio o 9 i 6 miejsc. Widać wyraźną różnicę między starymi i nowymi krajami Unii. Wynik osiągnięty przez lidera rankingu - Szwecję - jest prawie o 40\% wyższy od ostatniej w rankingu Bułgarii. Większość krajów starej piętnastki znajduje się w czołówce rankingu, a ich wyniki przekraczają średnią dla całej Unii. Z dwunastu nowych krajów Unii jedynie Estonia uzyskała wynik powyżej średniej i wyprzedziła m.in. Luksemburg oraz 2. co do wielkości gospodarkę Unii - Francję i 5. gospodarkę Unii - Hiszpanię. Z krajów starej Unii w tyle znalazły się trzy kraje z grupy PIGS: Włochy, Portugalia i Grecja. Dalekie miejsce Grecji wynika głównie ze słabości systemu instytucjonalnego w tym kraju. Polska osiągnęła wynik 7,41 - taki sam jak Łotwa, i zajęła jedną z ostatnich pozycji.

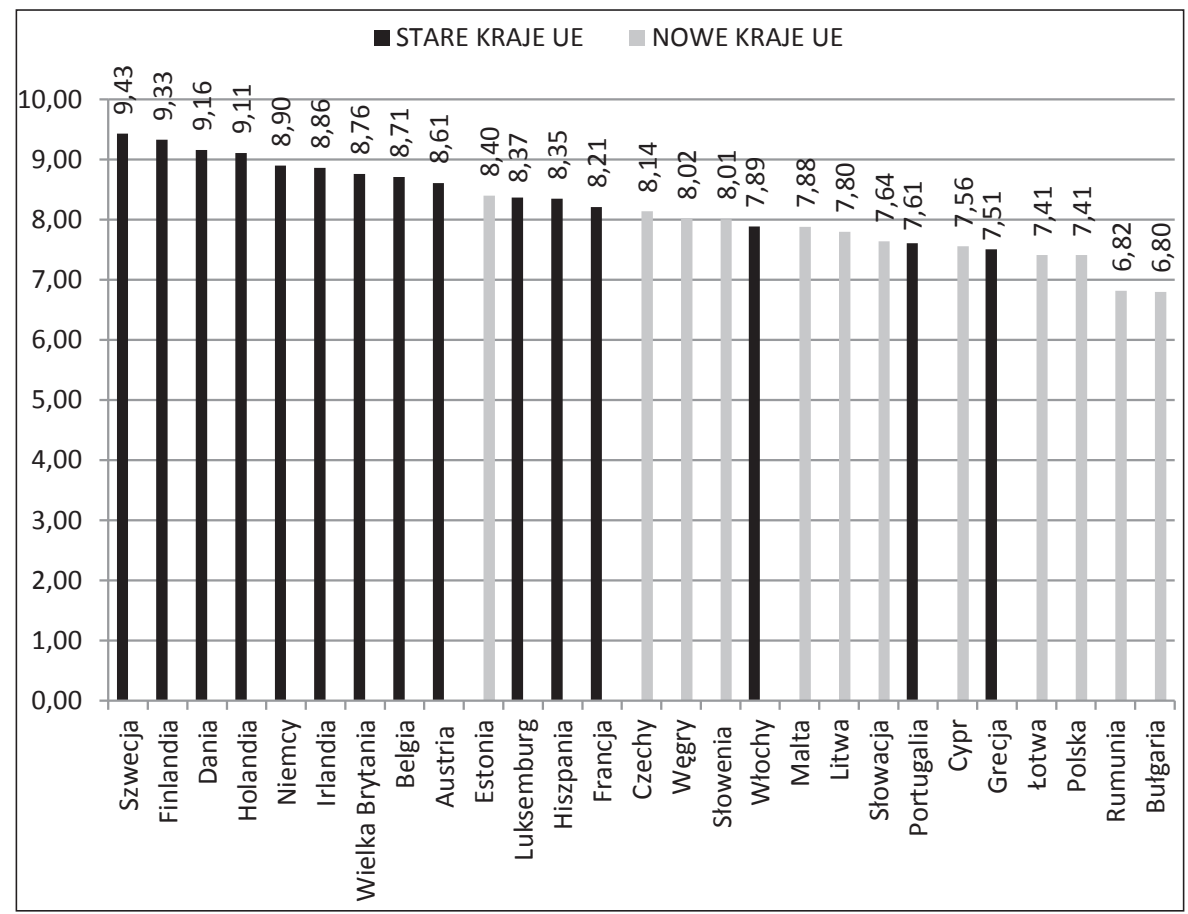

Ryc.1. Ranking krajów UE-27 na podstawie wskaźnika KEI w 2012 r.

Źródło: opracowanie własne na podstawie www.worldbank.org/kam (dostęp 15.11.2012)

Ranking krajów UE-27 na podstawie wskaźnika KI nie odbiega specjalnie od tego na podstawie KEI. Nie jest to zaskakujące ze względu na metodologię pomiaru, według której 
wskaźnik KI stanowi około 3/4 wartości wskaźnika KEI i jest uzupełniony o zestaw wskaźników mieszczących się w filarze: układ bodźców gospodarczych (ang. economic and institutional regime). Podobnie jak w rankingu KEI w czołówce są te same kraje: Szwecja, Finlandia, Holandia, Dania i Niemcy. Różnica między najlepszymi a najgorszymi krajami w tym rankingu jest na podobnym poziomie jak w zestawieniu na podstawie KEI. Z nowych krajów Unii ponownie pozytywnie wyróżnia się Estonia, która znalazła się na 11. miejscu, oraz Czechy na 14. miejscu, które zostały sklasyfikowane przed Włochami. Polska znajduje się na 24. miejscu, wyprzedzając jedynie: Łotwę, Rumunię i Bułgarię. Oznacza to, że czynniki instytucjonalne służące wykorzystaniu wiedzy są lepsze w Polsce niż na Łotwie.

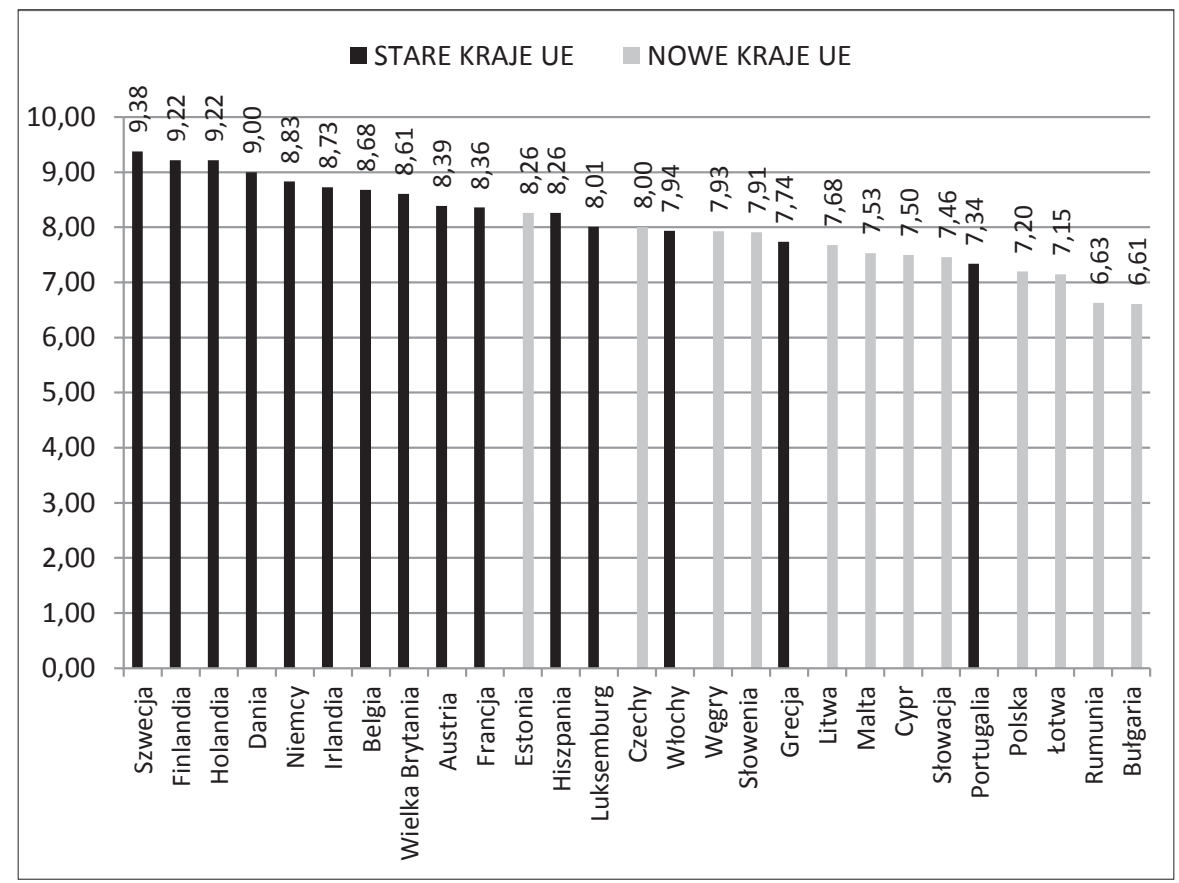

Ryc. 2. Ranking krajów UE-27 na podstawie wskaźnika KI w 2012 r.

Źródło: opracowanie własne na podstawie www.worldbank.org/kam (dostęp 15.11.2012)

Europejscy liderzy rankingu gospodarek opartych na wiedzy według wskaźników KEI i KI są równocześnie liderami światowego rankingu (zob. ryc. 3), który obją 146 państw w 2012 roku. Czołówki rankingów pozostają te same: Szwecja, Finlandia, Dania i Holandia. W grupie 20 najbardziej rozwiniętych gospodarek opartych na wiedzy w świecie aż 14 to gospodarki europejskie - 12 gospodarek krajów UE-27 oraz Norwegia i Szwajcaria. Na 19. miejscu w świecie sklasyfikowana została Estonia. Spoza Europy w czołowej dwudziestce znalazły się: Nowa Zelandia, Kanada, Australia, Stany Zjednoczone, Tajwan i Hongkong. Cztery kraje: Holandia, Stany Zjednoczone, Tajwan i Australia, uzyskały wskaźnik KI na wyższym poziomie niż KEI. 


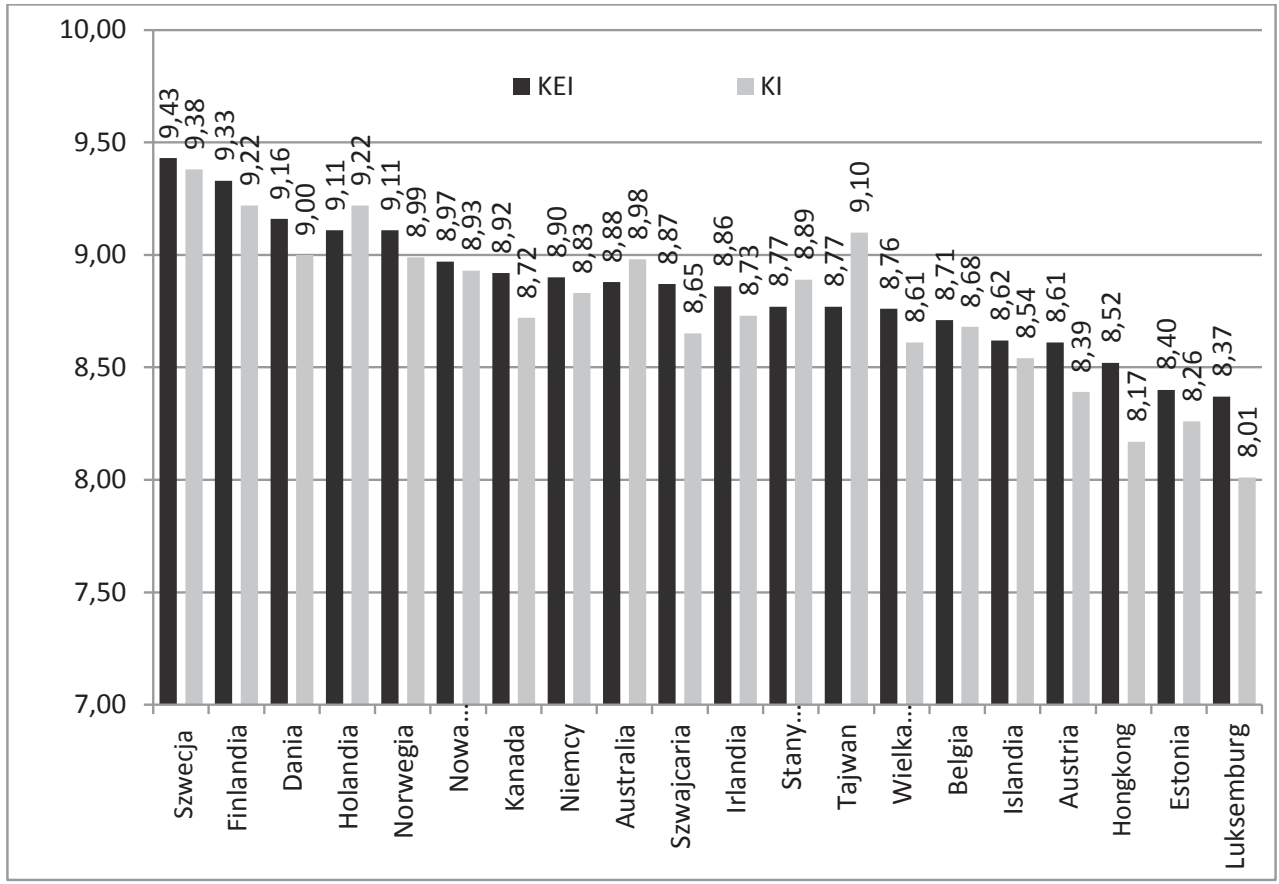

Ryc. 3. 20 najbardziej rozwiniętych gospodarek opartych na wiedzy (GOW) w 2012 r.

Źródło: opracowanie własne na podstawie www.worldbank.org/kam (dostęp 20.11.2012)

Reżim bodźców instytucjonalno-prawnych jest filarem, który obejmuje wskaźniki ze sfery otoczenia gospodarki. Układ krajów UE-27 według tego filara burzy klarowny podział na lepsze kraje starej i gorsze kraje nowej Unii. Krajami, w których system prawa i władza publiczna najbardziej sprzyjają rozwojowi gospodarki opartej na wiedzy, są: Finlandia, Dania, Szwecja i Luksemburg. Z nowych krajów unijnych lepiej niż przeciętnie wypadają Malta i Estonia (odpowiednio 9. i 10. miejsce). Za nimi na 11. miejscu znalazła się Holandia, a dopiero na 22. miejscu Włochy i 23. Francja. Ostatnie miejsce zajęła Grecja. Polska w tym rankingu wypada nie najgorzej i zajmuje 21. miejsce przed Włochami i Francją.

Ocena krajów według systemu innowacji pokazuje duże różnice między nowymi i starymi krajami Unii. Dysproporcje są tutaj największe - wynosi blisko 60\%. Liderami rankingu są te same kraje co według rankingu KEI: Szwecja, Finlandia, Dania i Holandia. Z nowych członków Unii najwyżej sklasyfikowana została Słowenia, która znalazła się na 12. miejscu, wyprzedzając m.in. Hiszpanię, Włochy, Grecję i Portugalię. Polska uzyskała wynik 7,16 i znalazła się w końcówce klasyfikacji, tj. przed: Bułgarią, Litwą, Łotwą i Rumunią. 


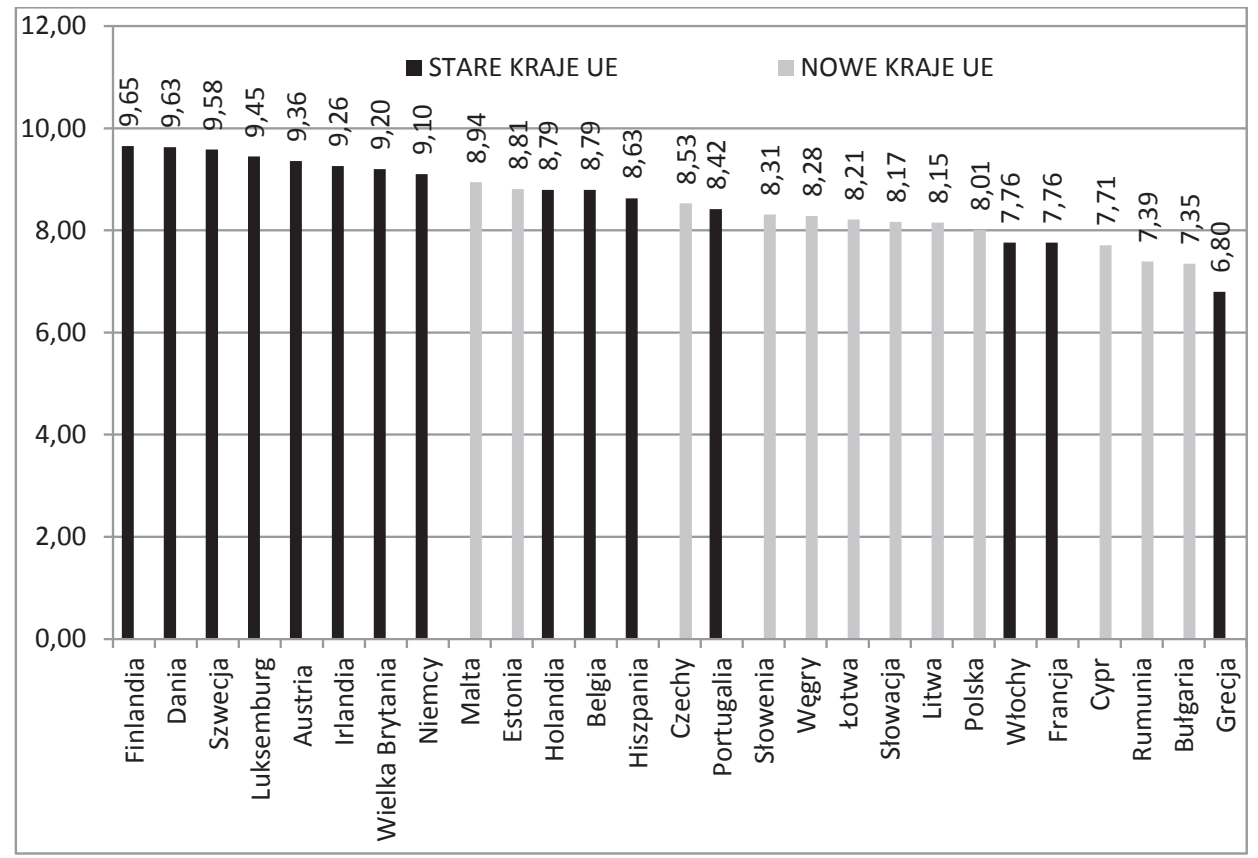

Ryc. 4. Ranking krajów UE-27 na podstawie filara Reżim prawno-instytucjonalny w 2012 r. Źródło: opracowanie własne na podstawie www.worldbank.org/kam (dostęp 22.11.2012)

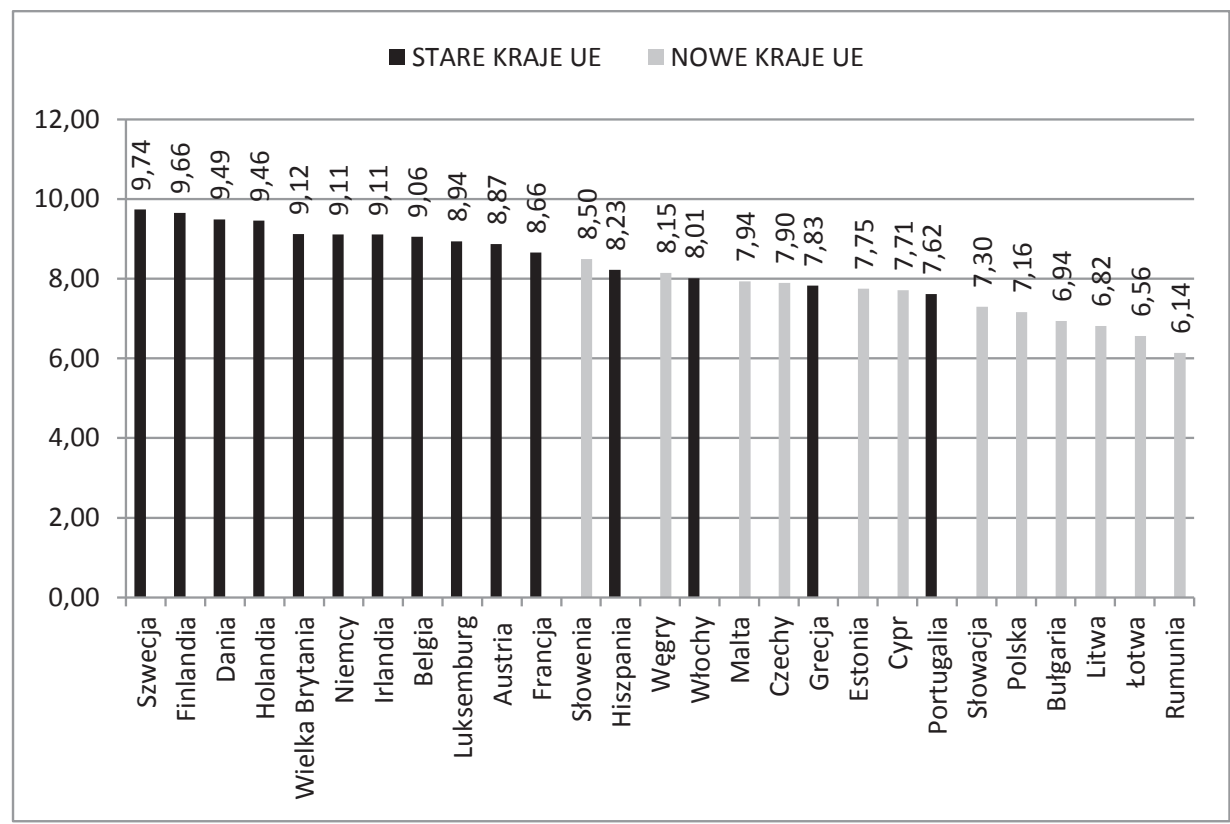

Ryc. 5. Ranking krajów UE-27 na podstawie filara System innowacji w 2012 r.

Źródło: opracowanie własne na podstawie www.worldbank.org/kam (dostęp 12.11.2012) 
Kolejność krajów na podstawie filara System innowacji pokrywa się w dużym stopniu z rankingiem z Unijnej tablicy innowacyjności (Nowak, 2012). Unijna tablica innowacyjności z 2011 r. oparta została na 24 wskaźnikach z zakresu badań naukowych oraz innowacji, które odzwierciedlają całokształt sytuacji innowacyjnej krajów. W tablicy wyników innowacyjności wykorzystano najnowsze dane Eurostatu i innych uznanych w skali międzynarodowej źródeł.

Wskaźniki Unijnej tablicy innowacyjności z 2011 r. podzielone zostały na trzy główne kategorie:

- „zasoby” (ang. enables), tj. podstawowe elementy umożliwiające zaistnienie innowacji (zasoby ludzkie, środki finansowe oraz wsparcie, otwarte i atrakcyjne systemy badawczo-naukowe);

- „aktywność przedsiębiorstw” (ang. firm activities) - ukazujące stopień innowacyjności europejskich firm (inwestycje, powiązania i przedsiębiorczość, aktywa intelektualne);

- „wyniki” (ang. outputs) - ilustrujące, w jaki sposób innowacyjność przekłada się na korzyści dla gospodarki (innowatorzy, skutki ekonomiczne).

Uwaga: Średnią innowacyjność mierzy się na podstawie syntetycznego wskaźnika skonstruowanego z danych dla 24 wskaźników - od minimalnego możliwego do uzyskania wyniku (0) do maksymalnego (1).

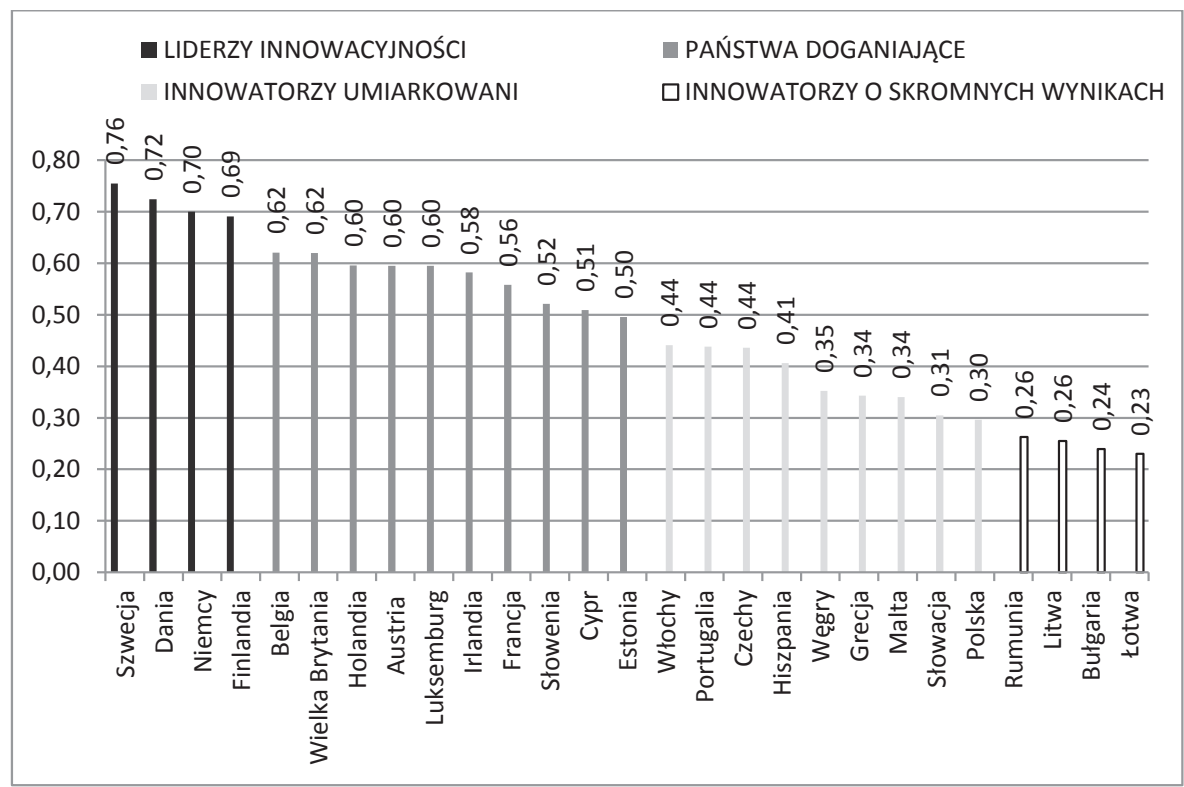

Ryc. 6. Wyniki państw UE-27 w dziedzinie innowacji na podstawie Unijnej tablicy innowacyjności z $2011 \mathrm{r}$.

Źródło: Unijna tablica innowacyjności z 2011 r., http:/ec.europa.eu/enterprise/policies/innovation/files/ius2011_en.pdf (dostęp 20.11.2012)

Średni wynik za rok 2011 z powodu opóźnienia w dostępności danych odzwierciedla dane z lat 2009-2010. Wyniki liderów innowacji (innovation leaders) przekraczają średnią 
o co najmniej 20\%; państw doganiających (innovation followers) - mieszczą się w zakresie od $10 \%$ poniżej średniej do $20 \%$ powyżej średniej; innowatorów umiarkowanych (moderate innovators) zawierają się w przedziale od $10 \%$ do $50 \%$ poniżej średniej; innowatorów o skromnych wynikach (modest innvators) poniżej 50\% średniej dla UE-27.

Liderami innowacji są: Szwecja, Dania, Niemcy i Finlandia. Państwa doganiające liderów, które osiągnęły wyniki zbliżone do średniej UE-27, to: Belgia, Wielka Brytania, Holandia, Austria, Luksemburg, Irlandia, Francja, Słowenia, Cypr i Estonia. Wyniki osiągane przez Włochy, Portugalię, Czechy, Hiszpanię, Węgry, Grecję, Maltę, Słowację i Polskę plasują się poniżej średniej dla UE-27. Są to umiarkowani innowatorzy. Wyniki osiągane przez Rumunię, Łotwę, Bułgarię i Litwę plasują się znacznie poniżej średniej dla UE-27. Są to innowatorzy o skromnych wynikach.

Ranking krajów według filara Edukacja i zasoby ludzkie w największym stopniu zakłóca podział na lepsze stare i gorsze nowe kraje Unii. Dysproporcje między krajami są największe spośród wszystkich rankingów i wynoszą około 60\%. Liderem i outsiderem listy są kraje starej piętnastki. Na początku rankingu plasuje się Grecja, a następnie Szwecja, Irlandia i Hiszpania. Na końcu listy znalazł się Luksemburg. Z krajów nowej Unii najwyżej sklasyfikowana została Litwa (7. miejsce), Estonia (9. miejsce) i Węgry (11. miejsce). Polska w tym rankingu znalazła się najwyżej spośród wszystkich przytaczanych rankingów - na 15. miejscu. Za nami znalazły się m.in.: Włochy, Austria, Wielka Brytania i Portugalia. Potwierdza to dość powszechną opinię o relatywnie mocnej pozycji naszego kraju pod względem wykształcenia społeczeństwa.

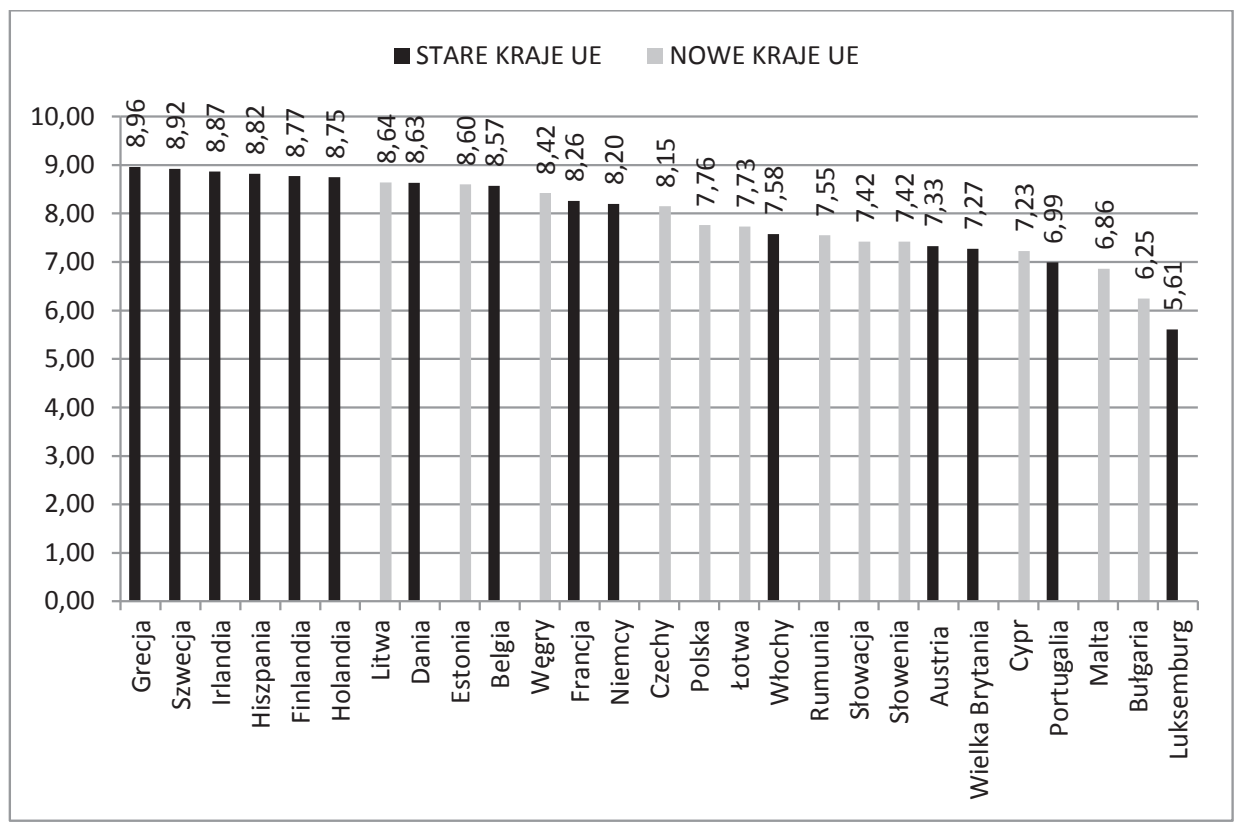

Ryc. 7. Ranking krajów UE-27 na podstawie filara Edukacja i zasoby ludzkie w 2012 r.

Źródło: opracowanie własne na podstawie www.worldbank.org/kam (dostęp 05.12.2012) 
Technologie komunikacyjne i informacyjne to ostatni filar, na którym opierają się wskaźniki KEI i KI. Liderami rankingu są: Szwecja, Luksemburg, Holandia i Wielka Brytania. Listę zamykają: Polska, Bułgaria, Grecja i Rumunia. Z nowych członków UE-27 wysoko notowana jest Estonia (9. miejsce), która wyprzedza m.in.: Belgię, Irlandię, Włochy, Francję i Hiszpanię. Ranking przedstawia wyraźny podział krajów Unii. Wyniki lepsze od średniej uzyskują stare kraje Unii, gorsze nowi członkowie.

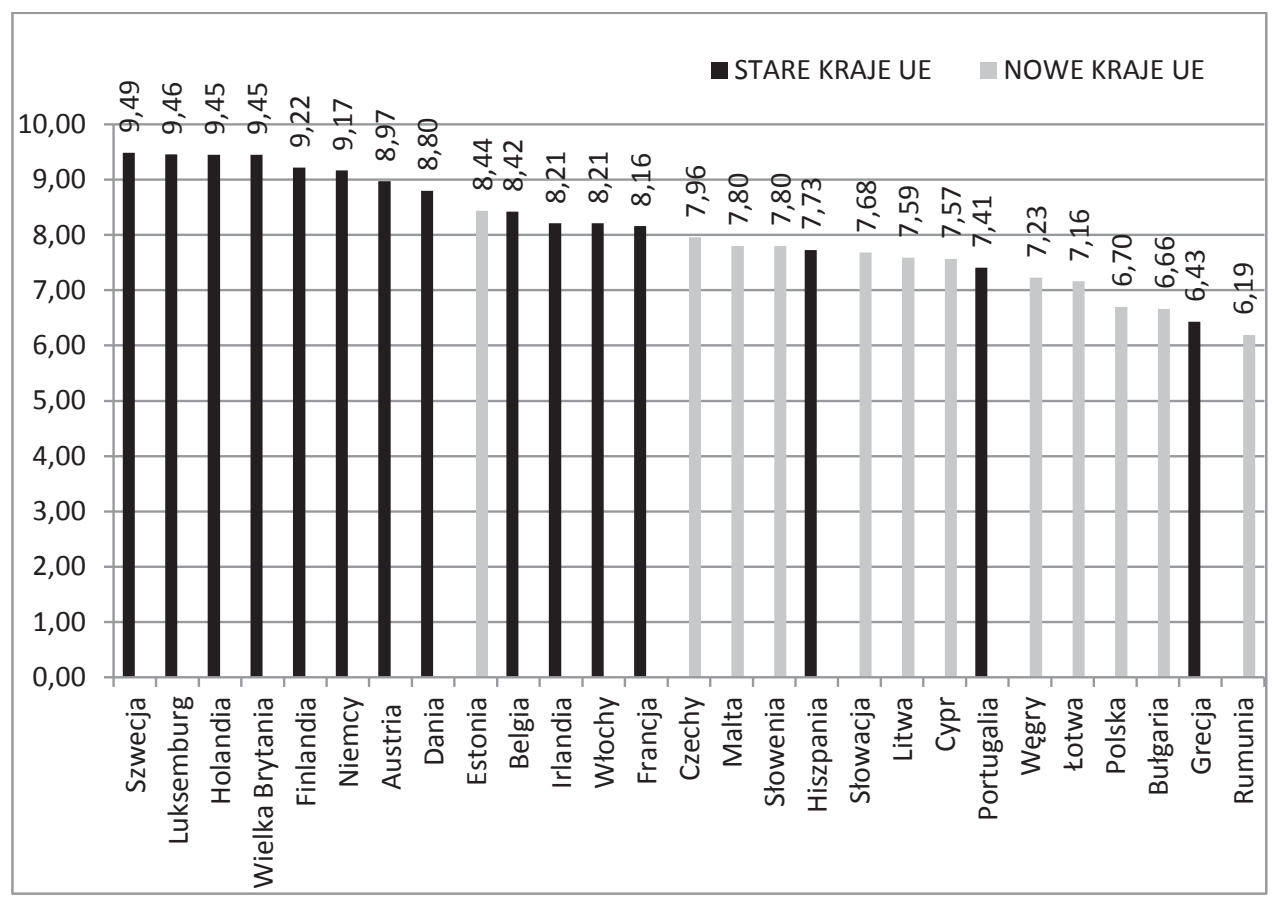

Ryc. 8. Ranking krajów UE-27 na podstawie filara

Technologie komunikacyjne i informacyjne w $2012 \mathrm{r}$.

Źródło: opracowanie własne na podstawie www.worldbank.org/kam (dostęp 05.12.2012)

Zróżnicowanie krajów członkowskich Unii na podstawie przytoczonych wskaźników wskazuje, że na ogół wyniki powyżej średniej mają stare, a poniżej średniej nowe kraje Unii. Widać to szczególnie wyraźnie w przypadku oceny na podstawie dwóch filarów: System innowacji i Technologie komunikacyjne i informacyjne. Nowe i stare kraje Unii stanowią dwa odmienne od siebie i odległe skupienia (Gierańczyk, 2009). Spośród starych krajów Unii najgorzej wypadają: Hiszpania, Włochy, Portugalia i Grecja. Ma to wpływ na pozycję krajów w końcowej klasyfikacji według kompleksowych wskaźników KEI i KI. Klasyfikacja krajów według dwóch pozostałych filarów: Reżim instytucjonalno-prawny oraz Edukacja i zasoby ludzkie nie przedstawia już tak czytelnego podziału - nowe kraje Unii zajmują wysokie pozycje w rankingach. Z nowych krajów Unii najwyżej oceniona została według filara: Reżim instytucjonalno-prawny - Malta (9. miejsce); Edukacja i zasoby ludzkie Litwa (7. miejsce); System innowacji - Słowenia (12. miejsce); Technologie komunikacyjne 
i informacyjne - Estonia (9. miejsce). W ogólnym rankingu KEI i KI z nowych krajów UE najwyżej oceniona została Estonia - odpowiednio 10. i 11. miejsce. Polska posiada jedną z najsłabiej rozwiniętych gospodarek opartych na wiedzy. Najlepszą pozycję zajmujemy w rankingu na podstawie filara Edukacja i zasoby ludzkie - 15. miejsce, a w ogólnej klasyfikacji według wskaźnika KEI i KI znajdujemy się na 25. i 24. miejscu w UE-27.

Tab. 1. Wartość wskaźników i filarów KEI dla Polski w latach 1995, 2000 i 2012 r.

\begin{tabular}{|c|c|c|c|c|c|c|c|}
\hline Rok & $\begin{array}{c}\text { Miejsce } \\
\text { Polski } \\
\text { w rankingu }\end{array}$ & KEI & KI & $\begin{array}{c}\text { Reżim prawno- } \\
\text {-instytucjonalny }\end{array}$ & $\begin{array}{c}\text { System } \\
\text { innowacji }\end{array}$ & $\begin{array}{c}\text { Edukacja } \\
\text { i zasoby } \\
\text { ludzkie }\end{array}$ & $\begin{array}{c}\text { Technologie } \\
\text { komunikacyjne } \\
\text { i informacyjne }\end{array}$ \\
\hline 1995 & 39 & 6,85 & 7,06 & 6,23 & 6,22 & 7,86 & 7,10 \\
\hline 2000 & 35 & 7,23 & 7,30 & 7,04 & 6,86 & 8,11 & 6,92 \\
\hline 2012 & 38 & 7,41 & 7,20 & 8,01 & 7,16 & 7,76 & 6,70 \\
\hline
\end{tabular}

Źródło: opracowanie własne na podstawie www.worldbank.org/kam (dostęp 10.12.2012)

Pozycja Polski w rankingu z 2012 r. uległa pogorszeniu w stosunku do miejsca w 2000 r. - spadek o 3 pozycje z 35 na 38 miejsce (zob. tab. 1). Poprawę wskaźników odnotowaliśmy w kategorii Reżim prawno-instytucjonalny i System innowacji przy równoczesnym pogorszeniu wskaźników Edukacja i zasoby ludzkie oraz Technologie komunikacyjne i informacyjne. Oznacza to, że w ujęciu bezwzględnym nasza sytuacja uległa poprawie, ale w stosunku do innych krajów, które rozwijały się szybciej, zanotowaliśmy regres. Polsce będzie trudniej niż innym europejskim państwom poprawić swoją pozycję w rankingu wartości kapitału ludzkiego. Powodem jest to, że w naszym kraju więcej dzieci rodzi się na wsi niż w mieście, a wszystkie wskaźniki brane pod uwagę na polskiej wsi są o wiele gorsze (Solska, 2012).

\section{DzIAŁANIA SŁuŻĄCE ROZWOJOWI GOW w ŚWIETle strategi Europa 2020}

Polska podjęła szereg zobowiązań, które powinny przełożyć się na poprawę w rankingach gospodarek opartych na wiedzy (Rachwał, 2010). Europa 2020 jest nową długookresową strategią rozwoju społeczno-gospodarczego Unii Europejskiej na lata 2010-2020. Została zatwierdzona przez Radę Europejską 17 czerwca 2010 r., zastępując w ten sposób realizowaną od 2000 r. i zmodyfikowaną pięć lat później strategii lizbońskiej. Strategia Europa 2020 jest zarówno kontynuacją wizji rozwoju nakreślonej w strategii lizbońskiej, jak i próbą odpowiedzi na słabości europejskiej gospodarki, które ujawniły się podczas światowego kryzysu finansowego 2008-2009, który uwidocznił poważne słabości strukturalne gospodarek europejskich.

Strategia Europa 2020 ma być europejską odpowiedzią na odczuwalne obecnie silniej niż jeszcze przed dekadą globalne wyzwania, w tym rosnącą konkurencję ze strony Stanów Zjednoczonych i wschodzących potęg gospodarczych - Indii i Chin, zmiany klimatu oraz wyczerpujące się zasoby naturalne czy obserwowany proces starzenia się społeczeństw, 
stanowiący poważne zagrożenie dla europejskiego modelu socjalnego. Rosnące wydatki na zabezpieczenie społeczne i opiekę zdrowotną będą niewątpliwie stanowiły jedno z najpoważniejszych wyzwań dla krajowych finansów publicznych w XXI wieku.

W tych warunkach jedynie odważne i skoordynowane działania - obejmujące europejskie instytucje, państwa członkowskie, regiony oraz partnerów społeczno-gospodarczych i przedstawicieli społeczeństwa obywatelskiego - są gwarancją sukcesu. Atutem Unii Europejskiej jest zaawansowany proces integracji gospodarczej oparty na instytucjach wolnego rynku i unii monetarnej, a dalsze znoszenie ograniczeń dla jednolitego rynku wewnętrznego mogłoby stanowić nowy impuls prowzrostowy.

Ważne jest przy tym wspieranie procesów harmonijnego rozwoju wszystkich regionów pozwalające zachować proporcjonalny udział poszczególnych państw członkowskich w osiąganiu celów strategii Europa 2020 (Annual..., 2013).

W opublikowanym 3 marca 2010 r. komunikacie: Europa 2020 - Strategia na rzecz inteligentnego i zrównoważonego rozwoju sprzyjającego włączeniu społecznemu podkreślona została potrzeba wspólnego działania państw członkowskich na rzecz wychodzenia z kryzysu oraz wdrażania reform umożliwiających stawienie czoła wyzwaniom związanym z globalizacją, starzeniem się społeczeństw czy rosnącą potrzebą racjonalnego wykorzystywania zasobów. Podstawowe cele reform, tzn. przyspieszenie wzrostu gospodarczego i zwiększenie zatrudnienia w Unii Europejskiej, nie uległy zmianie, zaproponowany model europejskiej społecznej gospodarki rynkowej w większym jednak niż dotychczas stopniu ma się opierać na trzech współzależnych i wzajemnie uzupełniających się priorytetach. Są to:

- inteligentny wzrost - oparty na wiedzy i innowacjach,

- zrównoważony wzrost - oparty na transformacji w kierunku gospodarki niskoemisyjnej, efektywnie korzystającej z zasobów i konkurencyjnej,

- wzrost sprzyjający włączeniu społecznemu - czyli wspieranie gospodarki charakteryzującej się wysokim poziomem zatrudnienia i zapewniającej spójność gospodarczą, społeczną i terytorialną.

Do oceny postępu w realizacji strategii Europa 2020 wybrano pięć wymiernych celów rozwojowych do osiągnięcia do 2020 r. na poziomie unijnym:

- Cel 1: osiągnięcie wskaźnika zatrudnienia na poziomie 75\% wśród kobiet i mężczyzn w wieku 20-64 lat, w tym przez zwiększenie zatrudnienia młodzieży, osób starszych i pracowników nisko wykwalifikowanych oraz skuteczniejszą integrację legalnych imigrantów.

- Cel 2: poprawa warunków prowadzenia działalności badawczo-rozwojowej, w szczególności z myślą o tym, aby łączny poziom inwestycji publicznych i prywatnych w tym sektorze osiągnął 3\% PKB; ponadto Komisja Europejska opracuje wskaźnik odzwierciedlający efektywność działalności badawczo-rozwojowej i innowacyjnej.

- Cel 3: zmniejszenie emisji gazów cieplarnianych o 20\%, w porównaniu z poziomami z 1990 r.; zwiększenie do 20\% udziału energii odnawialnej w ogólnym zużyciu energii; dążenie do zwiększenia efektywności energetycznej o 20\%. Unia Europejska zdecydowana jest podjąć decyzję o osiągnięciu do 2020 r. 30\% redukcji emisji w porównaniu z poziomem z 1990 r., pod warunkiem że inne kraje rozwinięte zobowiążą się do porównywalnych ograniczeń, a kraje rozwijające się wniosą wkład na miarę swoich zobowiązań i możliwości. 
- Cel 4: podniesienie poziomu wykształcenia, zwłaszcza przez dążenie do zmniejszenia odsetka osób zbyt wcześnie kończących naukę do poniżej 10\% oraz przez zwiększenie do co najmniej $40 \%$ odsetka osób w wieku 30-34 lata mających wykształcenie wyższe lub równoważne.

- Cel 5: wspieranie włączenia społecznego, zwłaszcza przez ograniczanie ubóstwa lub wykluczenia społecznego co najmniej $20 \mathrm{mln}$ obywateli.

Wyznaczone cele są silnie współzależne. Przykładowo: wzrost stopy zatrudnienia powinien pociągnąć za sobą ograniczanie rozmiarów ubóstwa wśród osób bezrobotnych i nieaktywnych zawodowo. Osiągnięcie celów gospodarki niskoemisyjnej nie będzie możliwe bez odpowiedniego zwiększenia nakładów na badania i rozwój czy szerszego wykorzystywania technologii informacyjno-telekomunikacyjnych (Kurek, 2010).

Oprócz celów dla całej Unii Europejskiej każdy kraj członkowski we współpracy z Komisją Europejską zobowiązany został do określenia krajowych celów rozwoju w powyższych pięciu obszarach, tak aby po zsumowaniu wszystkich działań można było osiągnąć wyznaczone cele unijne. Przyjmując krajowe cele strategii Europa 2020, rządy biorą pod uwagę stan wyjściowy gospodarki, co oznacza, że kraje startujące z lepszej pozycji niż pozostałe powinny podjąć bardziej ambitne zobowiązania (Strategia ..., 2012).

W kwietniu 2011 r. państwa członkowskie UE przekazały do KE Krajowe Programy Reform (KPR) na rzecz realizacji strategii Europa 2020, których celem jest budowa trwałych podstaw wzrostu gospodarczego, łącząc cele unijne z priorytetami krajowymi. Przedstawione w nich reformy, ukierunkowane na wzrost inteligentny, zrównoważony i sprzyjający włączeniu społecznemu, mają umożliwić przezwyciężenie zidentyfikowanych barier wzrostu hamujących potencjał rozwojowy państw członkowskich UE, jednocześnie przyczyniając się do wzmocnienia pozycji UE na arenie międzynarodowej (zob. tab. 2).

Tab. 2. Cele ogólnounijne i krajowe w ramach strategii Europa 2020

\begin{tabular}{|c|c|c|}
\hline Cele & $\begin{array}{l}\text { Wskaźnik realizacji } \\
\text { celu dla całej UE }\end{array}$ & $\begin{array}{l}\text { Wskaźnik realizacji } \\
\text { celu dla Polski }\end{array}$ \\
\hline Zwiększenie zatrudnienia & $\min .75 \%$ & $\min .71 \%$ \\
\hline Zwiększenie wydatków na badania i rozwój & $\min .3 \% \mathrm{PKB}$ & $\min .1,7 \%$ PKB \\
\hline $\begin{array}{l}\text { Ograniczenie emisji } \mathrm{CO}^{2} * \text { (w odniesieniu do poziomu } \\
\text { z } 1990 \text { r.) }\end{array}$ & $\min .-20 \%$ & $\max .14 \%$ \\
\hline $\begin{array}{l}\text { Zwiększenie udziału energii odnawialnej w bilansie } \\
\text { energetycznym }\end{array}$ & $\min .20 \%$ & $\min .15,48 \%$ \\
\hline $\begin{array}{l}\text { Poprawa efektywności energetycznej - ograniczenie } \\
\text { zużycia energii }\end{array}$ & $\min .20 \%$ & $\min .14 \%$ \\
\hline Ograniczenie przedwczesnego kończenia nauki & $\max .10 \%$ & $\max .4,5 \%$ \\
\hline Zwiększenie liczby osób z wykształceniem wyższym & $\min .40 \%$ & $\min .45 \%$ \\
\hline $\begin{array}{l}\text { Zmniejszenie liczby ludności zagrożonej ubóstwem } \\
\text { lub wykluczeniem społecznym (w liczbie osób) }\end{array}$ & $\min .20000000$ & $\min .1500000$ \\
\hline
\end{tabular}

* Krajowe cele w zakresie ograniczenia emisji, określone w decyzji 2009/406/WE (zwanej też decyzją dotyczącą wspólnego wysiłku redukcyjnego) odnoszą się do emisji nieobjętych systemem handlu emisjami. Emisje objęte systemem handlu emisjami zostaną ograniczone o $21 \%$ w porównaniu z poziomem emisji w 2005 r. Odnośne ograniczenie całkowite emisji wyniesie $20 \%$ w porównaniu z poziomem w $1990 \mathrm{r}$.

Źródło: http://ec.europa.eu/europe2020/pdf/targets_en.pdf (dostęp 05.12.2012) 
Prawie wszystkie wskaźniki potwierdzające realizację postawionych celów w ramach strategii Europa 2020 zostały sformułowane w wartościach relatywnych, tylko ostatni, dotyczący ograniczenia liczby ludności zagrożonej ubóstwem, został sformułowany w ujęciu absolutnym. Cele będą zrealizowane, jeżeli do 2020 roku osiągnięte zostaną związane z nimi wskaźniki. Wskaźniki sformułowane zostały jako minimalne lub maksymalne wartości. W większości przypadków cele Polski są mniej ambitne niż w całej Unii Europejskiej. Tylko w odniesieniu do przedwczesnego zakończenia nauki i liczby osób z wykształceniem wyższym Polska przyjęła na siebie wyższe wymagania nich Unia. Potwierdza to względnie mocną pozycję naszego kraju w zakresie edukacji i zasobów ludzkich.

Instrumentami realizacji celów strategii Europa 2020 są opracowywane przez państwa członkowskie UE Krajowe Programy Reform oraz przygotowane przez Komisję Europejską inicjatywy przewodnie, realizowane na poziomie UE, państw członkowskich, władz regionalnych i lokalnych.

Obecnie UE realizuje siedem inicjatyw przewodnich (Strategia..., 2012):

- Unia innowacji - poprawa warunków ramowych dla innowacji oraz wykorzystanie innowacji do rozwiązania najważniejszych problemów społecznych i gospodarczych wskazanych w strategii Europa 2020;

- Mobilna młodzież - poprawa jakości na wszystkich poziomach edukacji i szkoleń oraz zwiększanie atrakcyjności europejskiego szkolnictwa wyższego na arenie międzynarodowej;

- Europejska agenda cyfrowa - osiągnięcie trwałych korzyści gospodarczych i społecznych z jednolitego rynku cyfrowego, opartego na dostępie do szerokopasmowego Internetu;

- Europa efektywnie korzystająca z zasobów - wsparcie zmiany w kierunku gospodarki niskoemisyjnej i efektywniej korzystającej z zasobów środowiska oraz dążenie do wyeliminowania zależności wzrostu gospodarczego od degradacji środowiska przyrodniczego;

- Polityka przemysłowa w erze globalizacji - poprawa warunków dla przedsiębiorczości, zwłaszcza MŚP, oraz wsparcie rozwoju silnej bazy przemysłowej, zdolnej do konkurowania w skali globalnej;

- Program na rzecz nowych umiejętności i zatrudnienia - stworzenie warunków do unowocześnienia rynków pracy przez ułatwienie mobilności pracowników i doskonalenie ich umiejętności, w celu zwiększenia poziomu zatrudnienia oraz zapewnienie trwałości europejskich modeli społecznych;

- Europejski program walki z ubóstwem - zapewnienie spójności gospodarczej, społecznej i terytorialnej przez pomoc osobom biednym i wykluczonym oraz umożliwienie im aktywnego uczestniczenia w życiu ekonomicznym i społecznym. 


\section{ZAKOŃCZENIE}

Polska gospodarka oparta na wiedzy jest słabo rozwinięta. Z jednej strony możemy mówić o względnie wysokim poziomie wykształcenia społeczeństwa, przynajmniej pod względem formalnym, z drugiej strony jednak istnieją duże bariery instytucjonalne i infrastrukturalne hamujące rozwój w innych zakresach. Układ gospodarczy i instytucjonalny stwarza słabe bodźce do efektywnego wykorzystania istniejącej i tworzenia nowej wiedzy oraz hamuje rozwój przedsiębiorczości. Do tego dochodzą dodatkowo niskie nakłady publiczne na badania i rozwój, niski poziom kształcenia ustawicznego, słaba znajomość obsługi komputera na podstawowym poziomie oraz krótki okres życia w zdrowiu.

Polskę cechuje niska jakość otoczenia instytucjonalnego. Długo trwa założenie i likwidacja firmy, jak również postępowanie sądowe. Dość uciążliwe jest płacenie podatków, a na pozwolenie na budowę czeka się najdłużej w naszej części świata. Najlepiej od lat wygląda sytuacja pod względem możliwości uzyskania kredytu i prawnej ochrony inwestorów.

Żaden z polskich regionów, nawet metropolitalny, nie ma wysokiego potencjału wiedzy. Polskie regiony zajmują zazwyczaj dalekie pozycje, podobnie jak inne regiony Europy Środkowo-Wschodniej, poza obszarami metropolitalnymi i wysoko uprzemysłowionymi. Stanowimy obszar peryferyjny pod względem rozwoju GOW, technologicznie i naukowo zapóźniony, a ponadto słabo zintegrowany z regionami sąsiednimi i układem globalnym.

Nie w każdym regionie istnieją odpowiednie warunki do tworzenia i wdrażania innowacji, konieczne przy budowie nowoczesnej gospodarki opierającej się na wiedzy. Najlepsze warunki dla rozwoju innowacyjności występują w regionach dobrze rozwiniętych. W warunkach polskich największe szanse na zbudowanie nowoczesnej oraz innowacyjnej gospodarki mają najlepiej rozwinięte obszary metropolitalne i uprzemysłowione. Podnoszenie innowacyjności regionów w Polsce próbuje się osiągnąć za pomocą Regionalnych Systemów Innowacji (RSI), w skład których wchodzą przedsiębiorstwa, władze regionalne, uczelnie, instytuty badawczo-rozwojowe, agencje rozwoju regionalnego, instytucje finansowe i kredytowe, a także organizacje działające na rzecz przedsiębiorczości i innowacji (m.in.: inkubatory przedsiębiorczości, regionalne centra transferu technologii, parki technologiczne i firmy konsultingowe).

\section{Literatura}

Annual Growth Survey 2013. (2012, 5 październik). Pozyskano z http://ec.europa.eu/europe2020/index_en.htm.

Chen, D.H.C., Dahlman, C.J. (2005). The Knowledge Economy, the KAM Methodology and World Bank Operations. Washington DC: World Bank.

Ciborowski, R., Grabowiecki, J. (2004). Innovation and Technological Competitiveness of Central and East European Countries. W: K. Piech (red.), The Knowledge-Based Economy in Transition Countries: Selected Issues. London: University College London - School of Slavonic and East European Studies, 175-200.

Dahlman, C.J. (1999). The Four Pillars of the Knowledge Economy. Washington: World Bank Institute. 
Europe 2020 target. (2012, 10 październik). Pozyskano z http://ec.europa.eu/europe2020/pdf/targets_ en.pdf.

Gierańczyk, W. (2009). Innowacyjność jako główny filar społeczeństwa informacyjnego Europy. Prace Komisji Geografii Przemystu Polskiego Towarzystwa Geograficznego, 13, 82-94.

Howitt, P. (1996). On Some Problems in Measuring Knowledge Based Growth. W: P. Howitt (red.), The Implications of Knowledge Based Growth for Micro-Economic Policies. Calgary: University of Calgary Press.

Hryniewicz, J.T. (2010). Gospodarka oparta na wiedzy a globalne procesy geopolityczne. Prace Komisji Geografii Przemystu Polskiego Towarzystwa Geograficznego, 15, 61-68.

Kurek, S. (2010). Przestrzenne zróżnicowanie poziomu rozwoju regionalnego w Unii Europejskiej w świetle wybranych mierników. Prace Komisji Geografii Przemystu Polskiego Towarzystwa Geograficznego, 16, 87-104.

Lundvall, B., Johnson, B. (1994). The Learning Economy. Journal of Industry Studies, 1 (2).

Machlup, E. (1962). The Production and Distribution of Knowledge in the United States. Princeton New York : Princeton University Press.

Nowak, P. (2012). Poziom innowacyjności polskiej gospodarki na tle krajów UE. Prace Komisji Geografii Przemystu Polskiego Towarzystwa Geograficznego, 19, 142-152.

Piech, K. (2006). Tempo wzrostu gospodarczego a rozwój gospodarki opartej na wiedzy. W: K. Grysa (red.), Rola informatyki w naukach społecznych. Kielce: Wydawnictwo Wyższej Szkoły Handlowej.

Rachwał, T. (2010). Struktura przestrzenna i działowa przemysłu Polski na tle Unii Europejskiej w dwudziestolecie rozpoczęcie procesów transformacji systemowej. Prace Komisji Geografii Przemystu Polskiego Towarzystwa Geograficznego, 16, 105-124.

Rachwał, T. (2011). Wpływ kryzysu na zmiany produkcji przemysłowej. Prace Komisji Geografii Przemystu Polskiego Towarzystwa Geograficznego, 17, 99-113.

Republic of Korea. Transition to a Knowledge-Based Economy. Report 20346-KO. (2012, 10 listopad). Pozyskano z http://www-wds.worldbank.org/servlet/WDSContentServer/ WDSP/IB/ 2000/08/14 /000094946 $0007210532051 /$ Rendered/P

Skyrme, D.J. (1999). Knowledge Networking, Creating the Collaborative Enterprise. Oxford: Butterworth-Heinemann.

Solow, R. (1957). Technical Change and the Aggregate Production Function. Review of Economics and Statistics, 39, 312-320.

Solska, J. (2012, 20 październik). Ranking społeczeństw Europy - czy da się wycenić kapitat ludzki?. Pozyskano z http://serwisy.gazetaprawna.pl/edukacja/artykuly/632179,solska_wyksztalceni_pracowici_kompetentni_a_dopiero_na_dwudziestym_miejscu_ranking_spoleczenstw_europy.html

Strategia Europa 2020. (2012, 12 wrzesień). Pozyskano z http://www.mg.gov.pl/Bezpieczenstwo+ gospodarcze/Strategia+Europa +2020

The Knowledge-Based Economy. (1996). Paris: OECD. Pozyskano z http://www.oecd.org/science/ scienceandtechnologypolicy/1913021.pdf

Unijna tablica innowacyjności 2011. (2011, 10 grudzień). Pozyskano z http://ec.europa.eu/enterprise/ policies/innovation/files/ius-2011_en.pdf

Witulska, N. (2003). Zarządzanie wiedzą w aspekcie osiągania przewagi konkurencyjnej. W: K. Piech, G. Szczodrowski (red.), Przemiany i perspektywy polskich przedsiębiorstw $w$ dobie integracji z Uniq Europejska. Warszawa: IW, 145-153.

World Development Report (1998/1999), http://web.worldbank.org/WBSITE/ EXTERNAL/ EXTDEC/ EXTRESEARCH/EXTWDRS/0, contentMDK:22293493 pagePK:478093 piPK:477627 the SitePK:477624,00.html\#fulltext (dostęp 25.11.2012). 
Paweł Nowak, dr, Uniwersytet Pedagogiczny w Krakowie, Instytut Politologii, Katedra Ekonomii i Polityki Gospodarczej.

Paweł Nowak posiada stopień doktora nauk ekonomicznych w zakresie ekonomii nadany przez Uniwersytet Ekonomiczny w Krakowie. Obecnie zatrudniony na stanowisku adiunkta w Katedrze Ekonomii i Polityki Gospodarczej Instytutu Politologii Uniwersytetu Pedagogicznego w Krakowie. Zainteresowania naukowe: mikro- i makroekonomia, polityka gospodarcza i społeczna, przedsiębiorczość, integracja i globalizacja, niepewność i prawa konsumenta, innowacyjna gospodarka.

Pawel Nowak holds a PhD degree in Economics obtained at the Cracow University of Economics. At present he is a Senior Lecturer at the Department of Economics and Economic Politics, Institute of Political Science, Pedagogical University of Cracow. Main research interests concern: micro- and macroeconomics, economic and social politics, entrepreneurship, integration and globalization, uncertainty and consumer rights, innovative economy.

adres/address: Uniwersytet Pedagogiczny w Krakowie, Instytut Politologii,

Katedra Ekonomii i Polityki Gospodarczej,

ul. Podchorążych 2, 30-084 Kraków, Polska

e-mail: gelb@wp.pl 